Original Article

\title{
Hematology and blood biochemistry profile of the freshwater stingray Potamotrygon magdalenae as a tool for population assessment in artificial environments
}

\author{
Perfil hematológico e bioquímico do sangue da arraia de água doce Potamotrygon \\ magdalenae como ferramenta para avaliação da população em ambientes artificiais
}

\author{
J. G. Pérez-Rojasa,b* (D), P. A. Mejía-Falla ${ }^{\mathrm{a}, \mathrm{c}}$ (D) A. F. Naviaa (iD, A. M. Tarazona ${ }^{\mathrm{b}}$ (D) and S. C. Pardo-Carrasco ${ }^{\mathrm{b}}$ (iD \\ aFundación Colombiana para la Investigación y Conservación de Tiburones y Rayas - SQUALUS, Cali, Colombia \\ bUniversidad Nacional de Colombia, Facultad de Ciencias Agrarias, Departamento de Producción Animal, Medellín, Colombia \\ cWildlife Conservation Society - WCS Colombia, Cali, Colombia
}

\begin{abstract}
Hematological and blood biochemical reference information is important to establish physiological status of freshwater stingray populations and improve care and management protocols in artificial environments. Here, we used a commercial freshwater stingray with high mortality rates in the market (Potamotrygon magdalenae), as an example to understand how artificial environments and handling protocols influence physiological status of captive freshwater stingrays. To this purpose, blood from five adult males and six adult females was collected to perform complete blood counts and blood chemistry analyses. All sampled animals showed good body condition with no differences between sexes. Differences between sexes were only found for the differential count of lymphocytes. Red blood results were consistent with previously studied potamotrygonids while white blood results showed higher values of leukocytes, thrombocytes, heterophils and lymphocytes in P. magdalenae compared to other Potamotrygonids. All types of leukocytes described for elasmobranchs were found except neutrophils and basophils. Blood metabolites showed an influence of ex situ diet in total protein, triglycerides and cholesterol. Glucose results were consistent while urea showed lower levels than those recorded for other freshwater stingrays. These results highlight the importance of physical, physiological and health analysis in freshwater stingrays as a part of welfare assessment to improve monitoring protocols and survival rates in public or private aquaria.
\end{abstract}

Keywords: animal health, batoids, blood chemistry, captivity, complete blood count, elasmobranch, ornamental trade.

\begin{abstract}
Resumo
A informação de referência hematológica e bioquímica do sangue é importante para estabelecer o estado fisiológico das populações de arraias de água doce e melhorar os protocolos de cuidado e manejo em ambientes artificiais. Aqui, usamos uma espécie comercial de arraia de água doce com elevadas taxas de mortalidade no mercado (Potamotrygon magdalenae) como espécie exemplo para compreender de que modo os ambientes artificiais e os protocolos de manipulação influenciam o estado fisiológico das arraias de água doce em cativeiro. Para este fim, foi coletado sangue de cinco machos adultos e seis fêmeas adultas para realizar contagens completas de células sanguíneas e análises bioquímicas de sangue. Todos os animais amostrados mostraram boa condição corpórea, sem diferenças entre os sexos. Diferenças entre os sexos foram encontradas só na contagem diferencial de linfócitos. Os resultados de células sanguíneas vermelhas foram consistentes com potamotrigonídeos previamente estudados, enquanto o leucograma revelou valores mais elevados de leucócitos, trombócitos, heterófilos e linfócitos em P. magdalenae, em comparação com outros potamotrigonídeos. Todos os tipos de leucócitos descritos para elasmobrânquios foram encontrados, exceto para neutrófilos e basófilos. Todos os tipos de leucócitos descritos para elasmobrânquios foram encontrados, exceto para neutrófilos e basófilos. Os metabólitos do sangue mostraram influência da dieta ex situ nas proteínas totais, triglicerídeos e colesterol. Os resultados da glicose foram consistentes, enquanto a ureia mostrou níveis mais baixos do que os registrados para outras espécies de arraias de água doce. Os resultados da glicose foram consistentes, enquanto a ureia mostrou níveis mais baixos em $P$. magdalenae. Estes resultados enfatizam a importância da análise física, fisiológica e de saúde em arraias de água doce como parte da avaliação do bem-estar para melhorar os protocolos de monitoramento e as taxas de sobrevivência em aquários públicos ou privados.
\end{abstract}

Palavras-chave: saúde animal, batoides, química do sangue, cativeiro, hemograma completo, elasmobrânquios, comércio ornamental.

*e-mail: jgperez@squalus.org

Received: February 6, 2020 - Accepted: July 30, 2020

This is an Open Access article distributed under the terms of the Creative Commons Attribution License, which permits unrestricted use, distribution, and reproduction in any medium, provided the original work is properly cited. 


\section{Introduction}

Hematology is a very useful tool to perform physiological assessment of health status in fish, given the ease of collection and analysis of the samples, the little impact it generates on the life quality of the individuals, and its complementarity with other evaluation and diagnosis routine practices (Walsh and Luer, 2004; Semeniuk et al., 2009; Oliveira et al., 2012, 2015). Analysis of blood constants has been used in fish as stress and disease indicators, for diets analysis, to establish individual and population variations (Adams et al., 2003; Semeniuk et al., 2009; Jerome et al., 2018), as well as to characterize metabolic and adaptive physiological strategies related to environmental variations (Gallagher et al., 2014; Oliveira et al., 2016a,b; Hammerschlag et al., 2018; Lambert et al., 2018). Similarly, studies on qualitative and quantitative characteristics of leukocytes may indicate particularities of the immune system of a given species or population (Tavares-Dias and Moraes, 2007; Sueiro et al., 2019). In captive animals, blood analysis allows to establish physiological status and analyze how animals that have been moved away from their natural environment can acclimate to artificial environments (Greene et al., 2018; Grant and Campbell, 2020).

Thirty-six freshwater stingray species comprise the Potamotrygonidae Family (Fricke et al., 2019), most of them with high ornamental interest that are commercialized and breeding in countries such as United States, Japan, Taiwan and Germany (Rosa, 1985; Lasso et al., 2013). Recent studies characterized blood constants in freshwater stingrays to: understand physiological effects of transportation (Brinn et al., 2012), provide technical information for breeding strategies in artificial environments (Oliveira et al., 2015), assess the effect of habitat or life stage on the hematological profiles of individuals, and the effect of the environment on these variables (Oliveira et al., 2016a,b). In addition, Brito et al. (2015) and Oliveira et al. (2015, 2016b) provided information on morphological characteristics, cytochemical aspects, parasitic fauna, and hematological, hormonal, and serum biochemical variables in seven freshwater stingray species with a high commercial interest in Brazil.

Potamotrygon magdalenae is an endemic species from Colombia restricted to the Magdalena, Cauca, Atrato, Catatumbo and San Jorge river basins (MejíaFalla et al., 2016). It is an entomophagous carnivore species with a marked preference for Diptera, Chironomidae and Ephemeroptera larvae (Lasso et al., 2013; MejíaFalla et al., 2016; Márquez-Velásquez et al., 2019). This species has a high ornamental interest, being one of the most exported species in Colombia and most of the animals captured for commercialization at the national and international trade are mostly small animals (disc width of 12-17 cm; Mejía-Falla et al., 2016). In addition, the Magdalena River Stingray presents high mortality rates in the ornamental market ( $\approx 85 \%$; Mejía-Falla et al., 2009) and high difficulty to successful acclimation to artificial environments (Mejía-Falla et al., 2016). Consequently, recent research has seek to develop specie-specific handling, care and breeding protocols in artificial environments, and apply animal welfare approach by assessing physical, physiological and behavioral conditions in order to enhance survival rates and life quality (Mejía-Falla et al., 2016; Pérez-Rojas, 2020).

In this scenario, the use of hematological and blood biochemical variables to assess physiological status in captive populations is a helpful diagnostic tool to improve care and management (Grant and Campbell, 2020) for this species. However, lack of reference values remains as the main challenge since it is necessary to establish these values of hematological and biochemical parameters in healthy animals. This study aimed to provide the first available characterization of hematology and blood chemistry of P. magdalenae living in an artificial environment.

\section{Materials and Methods}

\subsection{Maintenance of captive stingrays}

We used 11 adult river stingrays ( $P$. magdalenae), five males (disc width, mean $\pm \mathrm{SD}$; DW = $15.4 \pm 0.5$; weight, $\mathrm{W}=276 \pm 27.0$ ) and six females ( $D W=20.3 \pm 1.3$; $W=533.3 \pm 75.3$ ), captured during 2013 in the middle basin of the Magdalena River (support permit of Autoridad Nacional de Acuicultura y Pesca, AUNAP, under the agreement AUNAP-SQUALUS №. 138/2013). From 2013 to 2017 these animals were used to conduct several research about ex situ transportation, acclimation, growth and reproduction (Mejía-Falla et al., 2016). During 2017, four years after their capture, with all the stingrays acclimated to artificial environment and showing successful reproductive events, we developed the present study as a component of $P$. magdalenae welfare assessment in captivity (PérezRojas, 2020). For this purpose, ex situ habitats prepared for the animals included four polypropylene tanks of $113 \mathrm{~cm}$ in diameter, $46 \mathrm{~cm}$ in height and $500 \mathrm{~L}$ capacity, which we designed and built in the facilities of the Animal Modeling Laboratory (LAMA) of Universidad Nacional de Colombia, Medellín campus. Two equal water recirculation systems were designed and constructed with mechanical and biological filtration, heating and aeration modules to maintain water quality and life support for the animals.

\subsection{Animal handling and blood collection}

In order to guarantee low stress impact and to safely draw blood samples from the animals, we used a two to three minutes immersion bath in water with eugenol $(0.2 \mathrm{~g} / \mathrm{L})$ to anesthetize the stingrays; complete blood extraction did not last more than 30 seconds. Once immobilized, they were measured (DW, cm) and weighed (W, g), and blood samples were then withdrawed by puncture of the branchial vessel and collected in tubes with EDTA 10\% and in tubes without anticoagulant (Vacuette ${ }^{\circledR}$, Greiner Bio-one, USA). The volume of obtained blood by each animal was less than $1 \%$ of the animal weight to avoid decompensation and kept adequate further health conditions. Once the sample was taken, the animals were kept in a tank with freshwater until they showed recovery signs such as actively moving and avoidance swimming from researcher stimuli. 
All anesthesia and blood collection procedures followed the indications of Oliveira et al. (2012) for freshwater stingrays and were in agreement with the ethical protocols endorsed by the Ethics Committee of Universidad Nacional de Colombia (CEMED-037).

\subsection{Body condition}

Body condition has been widely used as proxy of animal health and nutrition stage as it reflects how successful is an individual in interacting with its environment and assimilating resources (Dibattista et al., 2007; Gallagher et al., 2014). Body condition metrics can be based on the relationship between the length and weight of an individual or multiple measurements of body girth (Irschick and Hammerschlag, 2014), depending on the species size and ease of collecting weight data (Gallagher et al., 2014). In this study, we used Fulton's condition factor (K) as a physical welfare indicator for captive stingrays (Ricker, 1975), using the following calculation: $K=\left(W / D W^{3}\right) \times 10$.

\subsection{Complete Blood Count ( $C B C$ ) and biochemistry}

To performed $\mathrm{CBC}$, hematocrit estimation and differential cell counting we used blood collected in tubes with $10 \%$ EDTA, while blood taken without anticoagulant was centrifuged at 3,500 rpm for five minutes to obtain serum for the blood biochemistry tests. Since one of the samples taken from a male individual was coagulated, it was used only for biochemistry analyzes.

CBC analysis for $P$. magdalenae included red and white blood parameters. Red blood parameters provide information about intensity of oxygen transportation into tissues and aerobic capacity, being useful to assess starvation, bacterial or parasites infections, scarcity of micronutrients (iron, cooper), and diagnose diseases such as anemia (Birchard, 1997; Beldomenico et al., 2008; Semeniuk et al., 2009; Sueiro et al., 2019). We estimated erythrocyte count (RBC), hematocrit (Ht), hemoglobin concentration $(\mathrm{Hb})$, mean corpuscular volume (MCV), mean hemoglobin volume (MCH), and mean corpuscular hemoglobin concentration (MCHC). RBC $\left(10^{6} . \mu \mathrm{L}^{-1}\right)$ was performed in a Neubauer chamber using the Natt-Herrick reagent and physiological saline solution as a diluent. Hematocrit was estimated using the microhematocrit technique, and hemoglobin concentration $(\mathrm{g} / \mathrm{dL})$ was measured by the cyanmethemoglobin method, reading in a spectrophotometer at $546 \mathrm{~nm}$. MCV (fL), $\mathrm{MCH}$ (pg), and MCHC (g/dL) were estimated following Wintrobe (1933).

White blood analysis included leukogram, thrombogram and differential counting of leukocyte types (DCL) as diagnostic tools to get information about health and immune responses due to environmental or stressful conditions, parasite infection and physical injuries; in addition, it allows identifying sources of altered health according to the proportion of types of leukocytes (Adams et al., 2003; Walsh and Luer, 2004; Ochs and Dawson, 2008). For total leukocyte and thrombocyte counts $\left(\mu \mathrm{L}^{-1}\right)$, as well as for the (DCL) on peripheral blood $\left(\mu \mathrm{L}^{-1} ; \%\right)$, smears stained with Grünwald-Giemsa-Wright dye (Walsh and Luer, 2004) were performed and read in an optical microscope (Advanced Optical Microscope, model no. JSZ6S, China). Non-mammalian nomenclature was used to identify Leukocytes types for DCL (Grant, 2015).

We used blood biochemistry analysis to assess physiological functions of the stingrays. Urea, the main metabolite in elasmobranch blood, gives information about homeostatic balance facing disturbances and stressors as well as kidney functioning (Adams et al., 2003). Triglycerides and cholesterol are useful to assess feeding habits, nutritional condition, energy storage, energetic reserves and pancreatic functioning (Bacha et al., 2011; Gallagher et al., 2014; Brito et al., 2015). Glucose assessment provides information about stress responses as it is the primary metabolic fuel source under stress conditions in elasmobranchs (Jerome et al., 2018; Lambert et al., 2018). Finally, serum and plasma proteins allow to assess dietary inadequacies and accumulation of antibodies, and therefore they can be used as an index of total protein reserves as well as proxies for health parameters (Semeniuk et al., 2009; Jain et al., 2011). Analysis of urea (mg/dL), triglycerides $(\mathrm{mg} / \mathrm{dL})$, cholesterol $(\mathrm{mg} / \mathrm{dL})$, glucose $(\mathrm{mg} / \mathrm{dL})$ and serum proteins $(\mathrm{g} / \mathrm{dL})$ were estimated through colorimetric methods using specific commercial kits for each of the parameters (BioSystems, Colombia) and reading at $500 \mathrm{~nm}$ for glucose, cholesterol and triglycerides, and $545 \mathrm{~nm}$ for serum protein in a blood chemistry analyzer (BioSystems A15, Biosystems, Barcelona, Spain). Plasma proteins ( $\mathrm{g} / \mathrm{dL}$ ) were measured using a refractometer, after blood centrifugation in the capillary tubes to measure hematocrit $(8,000 \mathrm{rpm}$ for five minutes).

\subsection{Statistical analysis}

Due to the low sample size and the fact that none of the analyzed data met the assumptions of normality (ShapiroWilk test $\mathrm{p}<0.05$ ) or homogeneity of variance (Levene's test $\mathrm{p}<0.05$ ) we used a nonparametric U-Mann-Whitney paired test to compare hematological and biochemical profiles between sexes using R (R Core Team). To explore potencial relationships among body condition $(\mathrm{K})$, with the most informative hematological variables (RBC, Hb, Ht, leukogram, thrombogram, leukocytes percentage of $\mathrm{DCL}$ ) and all blood biochemichal variables, we conducted a correlation's matrix test, using PAST software V.4.02 (Hammer et al., 2001). In all cases, statistical significance were declared at $\mathrm{p}<0.05$.

\section{Results}

Body condition ranged from 0.50 to 0.80 for females $($ median $=0.64)$ and $0.61-0.85$ for males $($ median $=0.81$ ) and showed no difference between sexes. Altought $\mathrm{K}<1$, which is commonly assumed as a low condition, none of the sampled animals show any physical evidence of health issues, with no injuries, skin lacerations or parasites prevalence. On the contrary, all stingrays fed regularly and show continuous reproduction events (every 3 to 3.5 months). Thus, and given that $\mathrm{K}$ is a specie-specific index, all the values obtained reflected a good body condition in the sampled population.

No differences were found between sexes in RBC, $\mathrm{Ht}, \mathrm{Hb}$, $\mathrm{MCV}, \mathrm{MCH}$ or MCHC (as shown in Table 1). Leukogram and thrombogram of $P$. magdalenae showed no differences 
Table 1. Morphological and red blood parameters profile in adults of Potamotrygon magdalenae in an artificial environment. Different highlighted letters indicate significant differences between sexes according to the Mann-Whitney U test.

\begin{tabular}{|c|c|c|c|c|c|}
\hline Parameter & Sex & Min & Max & Median & P25-P75 \\
\hline \multicolumn{6}{|c|}{ Physical variables $\left(n_{\text {Females }}=6 ; n_{\text {Males }}=5\right)$} \\
\hline \multirow{2}{*}{ K } & $\mathrm{F}$ & 0.50 & 0.80 & 0.64 & $0.60-0.65$ \\
\hline & M & 0.61 & 0.85 & 0.81 & $0.70-0.83$ \\
\hline \multicolumn{6}{|c|}{$\operatorname{Red} \operatorname{series}\left(n_{\text {Females }}=6 ; n_{\text {Males }}=4\right)$} \\
\hline \multirow{2}{*}{$\operatorname{RBC}\left(10^{6} \cdot \mu \mathrm{L}^{-1}\right)$} & $\mathrm{F}$ & 0.18 & 0.35 & $0.25^{\mathrm{a}}$ & $0.22-0.28$ \\
\hline & M & 0.23 & 0.33 & $0.25^{\mathrm{a}}$ & $0.24-0.27$ \\
\hline \multirow{2}{*}{$\mathrm{Hb}(\mathrm{g} / \mathrm{dL})$} & $\mathrm{F}$ & 4.40 & 5.70 & $4.95^{\mathrm{a}}$ & $4.83-5.30$ \\
\hline & $\mathrm{M}$ & 3.50 & 4.80 & $4.55^{\mathrm{a}}$ & $4.10-4.80$ \\
\hline \multirow{2}{*}{$\mathrm{Ht}(\%)$} & $\mathrm{F}$ & 18.0 & 25.0 & $20.50^{\mathrm{a}}$ & $18.50-21.75$ \\
\hline & M & 15.0 & 20.0 & $18.0^{\mathrm{a}}$ & $16.50-19.25$ \\
\hline \multirow{2}{*}{$\mathrm{MCV}(\mathrm{fL})$} & $\mathrm{F}$ & 714.20 & 1028.0 & $806.0^{\mathrm{a}}$ & 727.13-944.08 \\
\hline & M & 523.0 & 833.0 & $706.05^{\mathrm{a}}$ & $619.83-778.25$ \\
\hline \multirow{2}{*}{ MHV (pg) } & $\mathrm{F}$ & 142.80 & 274.20 & $213.85^{\mathrm{a}}$ & $169.95-243.05$ \\
\hline & M & 132.30 & 200.0 & $172.05^{\mathrm{a}}$ & $147.15-194$ \\
\hline \multirow{2}{*}{ MCHC (g/dL) } & $\mathrm{F}$ & 20.0 & 27.20 & $25.80^{\mathrm{a}}$ & $22.93-26.43$ \\
\hline & M & 23.30 & 25.20 & $24.60^{\mathrm{a}}$ & $23.83-25.20$ \\
\hline
\end{tabular}

Mean and SD are shown to facilitate comparisons with other studies. F: Females; M: Males; K: Body condition; RBC: Erythrocyte count; Hb: hemoglobin concentration; Ht: hematocrit; MCV: Mean corpuscular volume; MHV: Mean hemoglobin volume; MCHC: Mean corpuscular hemoglobin concentration.

Table 2. White blood parameters profile in adults of Potamotrygon magdalenae in an artificial environment. Different highlighted letters indicate significant differences between sexes according to the Mann-Whitney U test.

\begin{tabular}{|c|c|c|c|c|c|}
\hline Parameter & Sex & Min & Max & Median & P25-P75 \\
\hline \multicolumn{6}{|c|}{ White series $\left(n_{\text {Females }}=6 ; n_{\text {Males }}=4\right)$} \\
\hline \multirow[t]{2}{*}{ Leukocytes $(/ \mu \mathrm{L})$} & $\mathrm{F}$ & 3,780 & 10,140 & $4,142.50^{\mathrm{a}}$ & $3,908.75-5,632.50$ \\
\hline & M & 6,125 & 11,615 & $9,145^{\mathrm{a}}$ & $7,868.75-10,283.75$ \\
\hline \multirow[t]{2}{*}{ Heterophils (\%) } & $\mathrm{F}$ & 18.0 & 74.0 & $42.0^{\mathrm{a}}$ & $33.0-51.75$ \\
\hline & M & 10.0 & 47.0 & $32.50^{\mathrm{a}}$ & $24.25-38.75$ \\
\hline \multirow[t]{2}{*}{ Heterophils $(/ \mu \mathrm{L})$} & $\mathrm{F}$ & 1,099 & 7,503 & $1,601.50^{\mathrm{a}}$ & $1,352-2,079.75$ \\
\hline & M & 1,162 & 3,972 & $2,529.50^{\mathrm{a}}$ & $1,944.25-3,133.50$ \\
\hline \multirow[t]{2}{*}{ Eosinophils (\%) } & $\mathrm{F}$ & 0.0 & 2.0 & $0.50^{\mathrm{a}}$ & $0.0-1.0$ \\
\hline & M & 0.0 & 0.0 & $0.0^{\mathrm{a}}$ & $0.0-0.0$ \\
\hline \multirow[t]{2}{*}{ Eosinophils $(/ \mu \mathrm{L})$} & $\mathrm{F}$ & 0.0 & 84.0 & $20.50^{\mathrm{a}}$ & $0.0-56$ \\
\hline & M & 0.0 & 0.0 & $0.0^{\mathrm{a}}$ & $0.0-0.0$ \\
\hline \multirow[t]{2}{*}{ Lymphocytes (\%) } & $\mathrm{F}$ & 25.0 & 76.0 & $53.50^{\mathrm{a}}$ & $44-62.25$ \\
\hline & M & 0.71 & 88.0 & $56.50^{\mathrm{a}}$ & $38.43-68.50$ \\
\hline \multirow[t]{2}{*}{ Lymphocytes $(/ \mu \mathrm{L})$} & $\mathrm{F}$ & 1,716 & 4,644 & $2,364.50^{\mathrm{a}}$ & $1,966-2,649.75$ \\
\hline & M & 3,798 & 10,221 & $5,647.50^{\mathrm{b}}$ & 4,181.25-7,794.75 \\
\hline \multirow[t]{2}{*}{ Monocytes (\%) } & $\mathrm{F}$ & 1.0 & 5.0 & $3.50^{\mathrm{a}}$ & $3.0-4.75$ \\
\hline & M & 0.0 & 2.0 & $2.0^{\mathrm{a}}$ & $1.50-2.0$ \\
\hline \multirow[t]{2}{*}{ Monocytes $(/ \mu \mathrm{L})$} & $\mathrm{F}$ & 101.0 & 306.0 & $140.0^{\mathrm{a}}$ & $123.75-180.25$ \\
\hline & M & 0.0 & 232.0 & $145.50^{\mathrm{a}}$ & $91.50-184.75$ \\
\hline \multirow[t]{2}{*}{ Thrombocytes $(/ \mu \mathrm{L})$} & $\mathrm{F}$ & 3,525 & 11,760 & $5,968.50^{\mathrm{a}}$ & $4,202.50-10478$ \\
\hline & $\mathrm{M}$ & 5,000 & 7,800 & $7,096.50^{\mathrm{a}}$ & 6,166.25-7678.50 \\
\hline
\end{tabular}

Mean and SD are shown to facilitate comparisons with other studies. F: Females; M: Males. 
between sexes either (as shown in Table 2). Four different types of white blood cells were identified in peripheral blood of P. magdalenae, as follows: heterophils, eosinophiles, lymphocytes and monocytes (see Figure 1); no basophils or neutrophils were found in any sampled animal and no eosinophils were found in the sampled males. Lymphocytes were the most representative type of white blood cell in P. magdalenae, both in concentration $(/ \mu \mathrm{L})$ and proportion (\%), followed by heterophils, monocytes and eosinophils ((as shown in Table 2). In the DCL, differences between sexes were only found for lymphocyte concentration ( $p=0.043$ ) ranging in females from 1,716 to $4,644 \mathrm{Lym} / \mu \mathrm{L}$
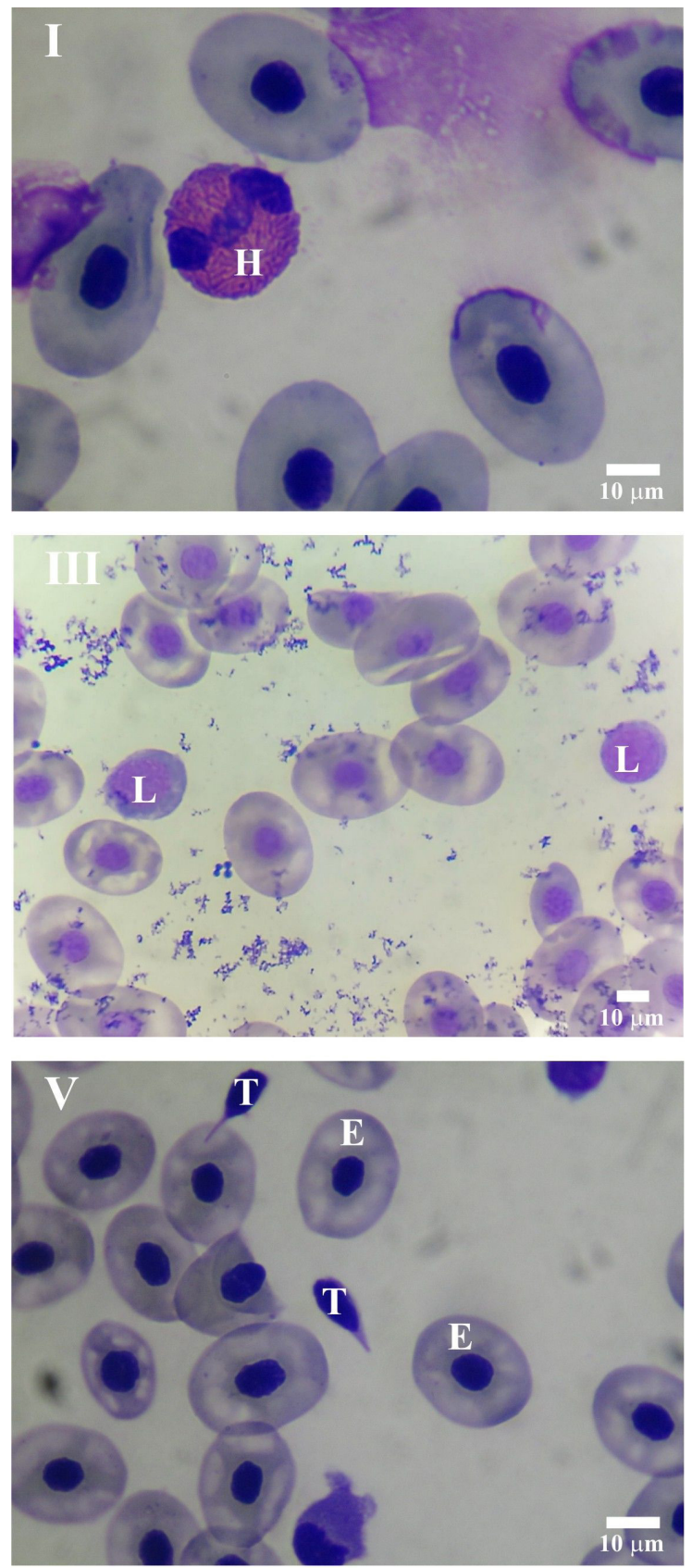

(median $=2,364.50 \mathrm{Lym} / \mu \mathrm{L}$ ) and in males from 3,798 to $10,221 \mathrm{Lym} / \mu \mathrm{L}($ median $=5,647.50 \mathrm{Lym} / \mu \mathrm{L}$; as shown in Table 2). The blood biochemistry assessment showed no differences between sexes in cholesterol, triglycerides, serum and plasma protein, urea and glucose levels (as shown in Table 3). Twelve of the 112 analyzed correlations among body condition and phisiological variables were significant, being seven positives and five negatives (see Figure 2). Significant positive correlations were found between: K-leukocites, RBC-serum proteins, $\mathrm{Hb}-\mathrm{Ht}$, thrombocytes-glucose, triglycerides-plasma proteins, triglycerides-cholesterol and plasma proteins-cholesterol
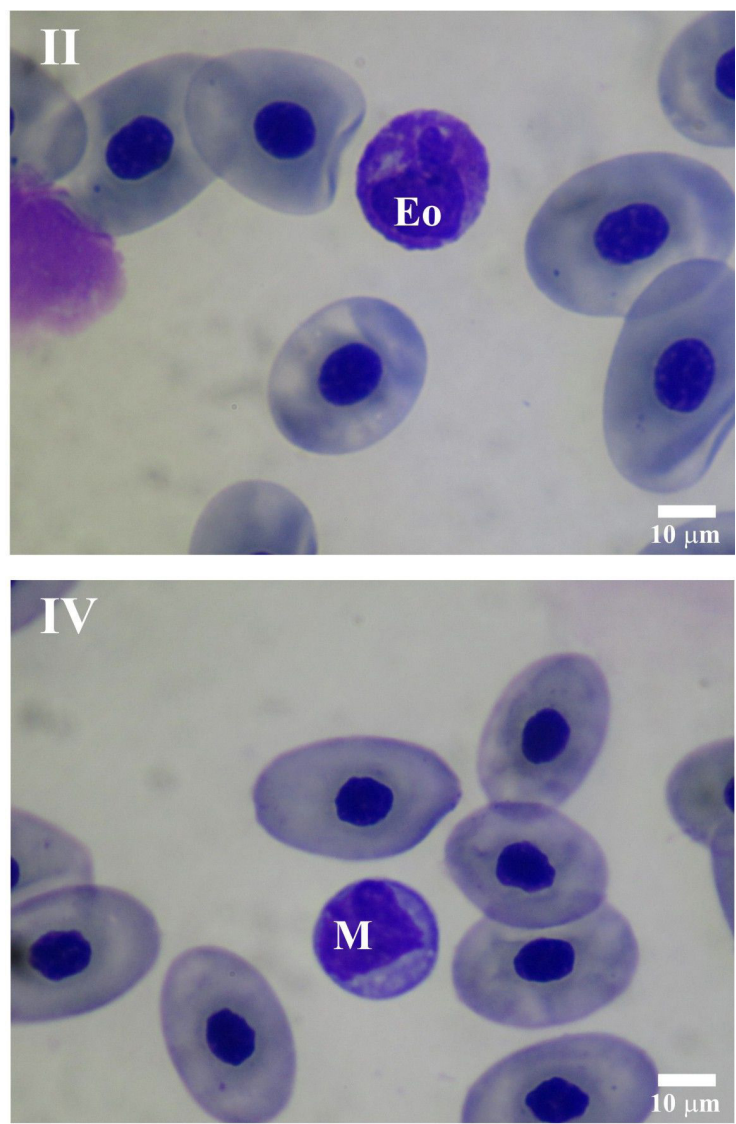

I) Heterophils $(\mathrm{H}), 100 \mathrm{x}$

II) Eosinophiles (Eo), 100x

III) Lymphocytes (L), 40x

IV) Monocytes (M), 100x

V) Thrombocytes $(\mathrm{T})$ and
erythrocytes $(\mathrm{E}), 100 \mathrm{x}$

Figure 1. Different cell types found in peripheral blood of captive adults of Potamotrygon magdalenae. 
Table 3. Blood biochemistry profile in adults of Potamotrygon magdalenae in an artificial environment. Different highlighted letters indicate significant differences between sexes according to the Mann-Whitney U test.

\begin{tabular}{|c|c|c|c|c|c|}
\hline Parameter & Sex & Min & Max & Median & P25-P75 \\
\hline \multicolumn{6}{|c|}{ Blood chemistry $\left(n_{\text {Females }}=6 ; n_{\text {Males }}=5\right)$} \\
\hline \multirow[t]{2}{*}{ Urea $(\mathrm{mg} / \mathrm{dL})$} & $\mathrm{F}$ & 2.0 & 8.0 & $5.0^{\mathrm{a}}$ & $5.0-7.25$ \\
\hline & M & 3.0 & 8.0 & $3.0^{\mathrm{a}}$ & $3.0-6.0$ \\
\hline \multirow[t]{2}{*}{ Triglycerides $(\mathrm{mg} / \mathrm{dL})$} & $\mathrm{F}$ & 2.0 & 92.0 & $37.50^{\mathrm{a}}$ & $29.75-65.50$ \\
\hline & M & 38.0 & 73.0 & $64.0^{\mathrm{a}}$ & $54.0-65.0$ \\
\hline \multirow[t]{2}{*}{ Plasma proteins $(\mathrm{g} / \mathrm{L})$} & $\mathrm{F}$ & 14.0 & 24.0 & $18.0^{\mathrm{a}}$ & $18.0-19.50$ \\
\hline & M & 20.0 & 26.0 & $20.0^{\mathrm{a}}$ & $20.0-21.50$ \\
\hline \multirow[t]{2}{*}{ Serum proteins $(\mathrm{g} / \mathrm{L})$} & $\mathrm{F}$ & 7.39 & 13.26 & $9.76^{\mathrm{a}}$ & $8.49-12.34$ \\
\hline & M & 6.76 & 13.38 & $11.30^{\mathrm{a}}$ & $9.54-11.31$ \\
\hline \multirow[t]{2}{*}{ Glucose (mg/dL) } & $\mathrm{F}$ & 21.0 & 35.0 & $24.0^{\mathrm{a}}$ & $22.50-25.50$ \\
\hline & M & 21.0 & 31.0 & $23 .^{a}$ & $22.0-26.0$ \\
\hline \multirow[t]{2}{*}{ Cholesterol (mg/dL) } & $\mathrm{F}$ & 30.0 & 72.0 & $42.50^{\mathrm{a}}$ & $37.75-54.75$ \\
\hline & M & 39.0 & 65.0 & $53.0^{\mathrm{a}}$ & $47.0-55.0$ \\
\hline
\end{tabular}

Mean and SD are shown to facilitate comparisons with other studies. F: Females; M: Males.

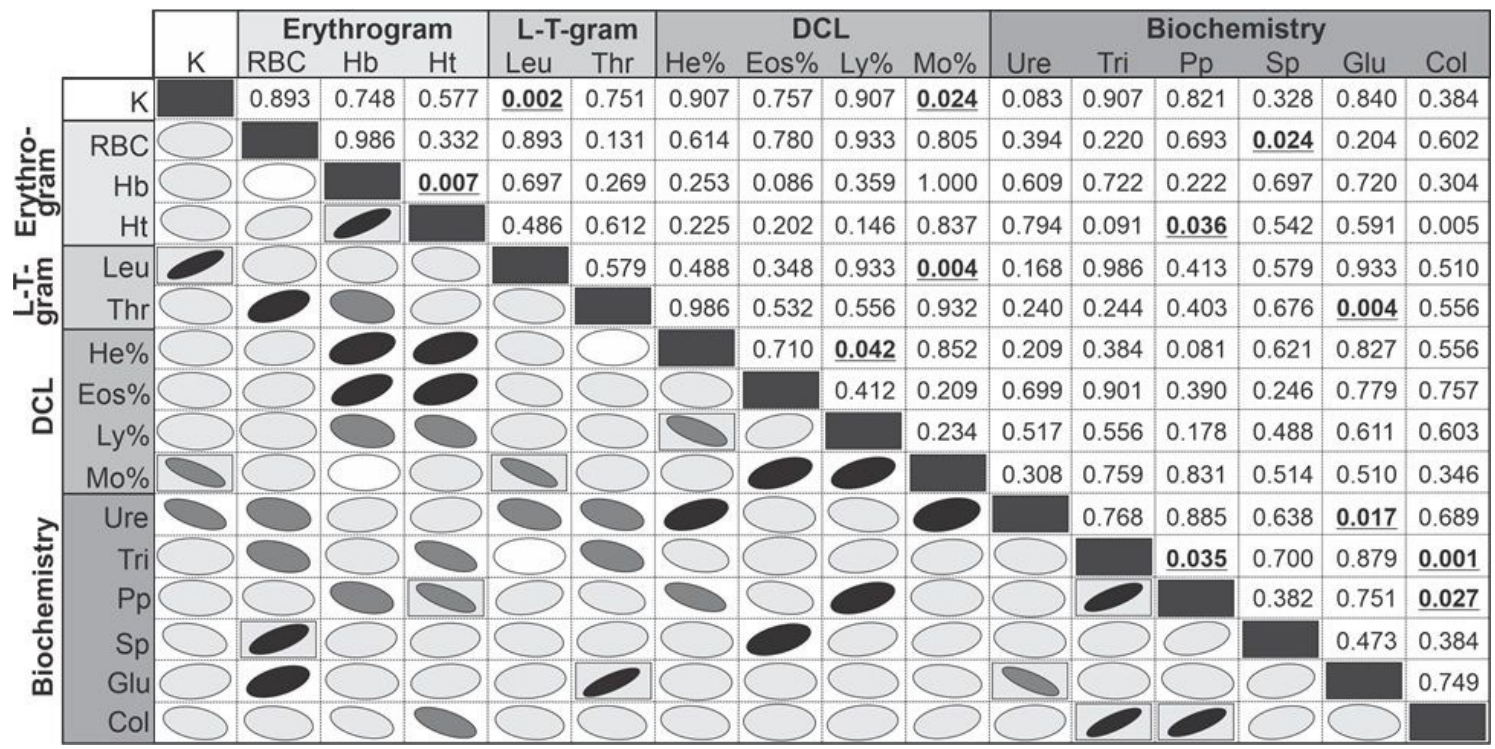

Figure 2. Correlation's matrix test among body condition and physiological parameters in captive adults of Potamotrygon magdalenae. RBC: Erythrocyte count; Hb: Hemoglobin; Ht: Hematocrit; Leu: Leukocte count; Thr: Thrombocyte count; He\%: Heterophils proportion; Eos\%: Eosinophils proportion; Ly\%: Lymphocytes proportion; Mo\%: Monocytes proportion; Ure: Urea; Tri: Triglycerides; Pp: Plasma proteins; Sp: Serum proteins; Glu: Glucose; Col: Cholesterol. Ellipses show the type of correlation between each variable, slope shows whether the correlation is positive or negative, color intensity shows the correlation's strength, and amplitude of the ellipse corresponds to the data dispersion. The upper diagonal shows the $\mathrm{p}$ values for each correlation.

(see Figure 2). Significant negative correlations were found between: K-monocytes (\%),Ht-plasma proteins, leukocytes-monocytes (\%), heterophils (\%)-lymphocytes (\%), and urea-glucose (see Figure 2).

\section{Discussion}

The absence of differences in red blood cell parameters between females and males in our work confirm the little variations of red blood parameters described in freshwater stingrays, without influence of sex, reproductive stage or species in wildlife populations (Brito et al. 2015; Oliveira et al., 2015, 2016b).

Our results about erythrogram show that although P. magdalenae have a smaller number of cells available, they are larger, providing a higher capacity to hold oxygen (as shown in Table 4). These physiological attributes are important for its survival in the environments of its natural distribution, characterized by low levels of dissolved oxygen 
(DO) and high temperatures (Mejía-Falla et al., 2014). Conditions of $\mathrm{DO}$, temperature and $\mathrm{pH}$ in ex situ habitats designed for $P$. magdalenae were highly similar to wildlife conditions (mean $\pm \mathrm{SD} \mathrm{DO}=4.89 \pm 1.05 \mathrm{mg} / \mathrm{L}$, temperature $=28.66 \pm 0.49$ and $\mathrm{pH}=7.95 \pm 0.61$; Pérez-Rojas, 2020) allowing us to infer that our results for the red blood parameters could be a natural physiologic feature for the species. However, water quality and habitat preferences of the species, as well as captivity effects can be reflected in variation of red blood parameters (Semeniuk et al., 2009; Oliveira et al., 2016a; Grant and Campbell, 2020), we highlight the importance of assessing physiological status of wildlife populations of $P$. magdalenae.

Lymphocytes and heterophils were the most representative type of leukocytes found, being consistent to blood cell proportions recorded to elasmobranchs (Smith et al., 2014) and some potamotrygonid species such as P. wallacei, P. motoro, Paratrygon aiereba, P. orbignyi and $P$. schroederi (Oliveira et al., 2015). The absence of neutrophils and basophils in $P$. magdalenae is not a rare result, since this has been reported in some freshwater stingray species (Oliveira et al., 2015), and basophils, when they are present, had a very low proportion (Walsh and Luer, 2004; Oliveira et al., 2015; Greene et al., 2018; Grant and Campbell, 2020). However, the absence of these cells could also be related to staining techniques and protocols that can induce degranulation of basophils (Ferreira et al., 2010), or conflicts in cells nomenclature and accurate morphological identification of elasmobranch blood cells (Walsh and Luer, 2004; Pádua et al., 2010; Oliveira et al., 2015). Therefore, a cytochemical study would confirm the results obtained in P. magdalenae and elucidate if neutrophils absence is characteristic of this species.

Potamotrygon magdalenae showed higher values of total leukocytes and thrombocytes than those reported for all freshwater stingray species currently studied (as show in Table 5). Higher values of heterophils $(\%, \mu \mathrm{L})$ and lymphocytes $(\%, / \mu \mathrm{L})$ and lower of monocytes $(\%, / \mu \mathrm{L})$ were also observed in comparison with other potamotrygonids. Eosinophil count was similar to other freshwater stingrays, while no comparison can be made in percentage since this is the first research that report it (as shown in Table 5). Although differences in DCL profile can be interespecific (Oliveira et al., 2016b), it might also be explained by

Table 4. Comparative view of red blood cell parameters (erythrogram) among freshwater stingrays, showing mean and standard deviation (SD) values.

\begin{tabular}{lccccccc}
\hline Species & RBC & Hb & Ht & MCV & MCH & MCHC & Reference \\
\hline P. falkneri & $0.8 \pm 0.1$ & $4.31 \pm 0.2$ & $21.3 \pm 0.8$ & $288.0 \pm 33$ & $57.1 \pm 5.9$ & $20.8 \pm 1.1$ & Brito et al. (2015) \\
P. motoro & $0.7 \pm 0.1$ & $4.19 \pm 0.4$ & $19.6 \pm 1.6$ & $325.0 \pm 59$ & $59.4 \pm 13$ & $22.2 \pm 1.9$ & Brito et al. (2015) \\
P. orbignyi & $0.9 \pm 0.1$ & $4.96 \pm 0.8$ & $23.1 \pm 3.9$ & $267.0 \pm 49$ & $54.5 \pm 9.8$ & $21.9 \pm 4.1$ & Brito et al. (2015) \\
P. scobina & $1.4 \pm 0.4$ & $5.22 \pm 1.1$ & $22 \pm 4.6$ & $171.0 \pm 33$ & $39.5 \pm 5.6$ & $23.7 \pm 2.2$ & Brito et al. (2015) \\
P. wallacei & $0.4 \pm 0.1$ & $4.0 \pm 0.9$ & $23.0 \pm 4.4$ & $529.8 \pm 144.5$ & $91.4 \pm 22.4$ & $18.7 \pm 4.9$ & Oliveira et al. (2015) \\
P. motoro & $0.3 \pm 0.1$ & $2.2 \pm 0.7$ & $14.6 \pm 3.7$ & $420.4 \pm 83.1$ & $62.8 \pm 14.9$ & $15.43 \pm 4.3$ & Oliveira et al. (2015) \\
P. aiereba & $0.4 \pm 0.1$ & $4.2 \pm 1.1$ & $24.7 \pm 4.1$ & $641.4 \pm 151.2$ & $105.8 \pm 39.7$ & $17.2 \pm 4.0$ & Oliveira et al. (2015) \\
P. orbignyi & $0.4 \pm 0.1$ & $3.8 \pm 0.9$ & $23.3 \pm 3.5$ & $663.9 \pm 226.8$ & $106.2 \pm 31.5$ & $16.2 \pm 2.0$ & Oliveira et al. (2015) \\
P. schroederi & $0.3 \pm 0.1$ & $3.7 \pm 0.9$ & $23.9 \pm 1.1$ & $892.2 \pm 670.0$ & $88.3 \pm 33.7$ & $15.6 \pm 9.7$ & Oliveira et al. (2015) \\
P. magdalenae & $0.3 \pm 0.1$ & $4.8 \pm 0.6$ & $19.5 \pm 2.8$ & $781.3 \pm 148.7$ & $192.9 \pm 47.3$ & $24.5 \pm 2.2$ & This study \\
\hline
\end{tabular}

RBC: Erythrocyte count $\left(10^{6} . \mathrm{LL}^{-1}\right)$; Hb: Hemoglobin (g/dL); Ht: Hematocrit (\%); MCV: Mean corpuscular volume (fL); MCH: Mean hemoglobin volume (pg); MCHC: Mean corpuscular hemoglobin concentration $(\mathrm{g} / \mathrm{dL})$.

Table 5. White blood parameters (leukogram) comparison among freshwater stingrays, showing average and standard deviation (SD) values.

\begin{tabular}{lccccccc}
\hline Species & Leu & Thr & Het & Eos & Lym & Mon & Reference \\
\hline P. falkneri & $3,618.0 \pm 399.0$ & $1,255.0 \pm 263.0$ & $232.0 \pm 34.0$ & $30.0 \pm 13.0$ & $1,123 \pm 411.0$ & $337.0 \pm 50.0$ & Brito et al. (2015) \\
P. motoro & $2,520.0 \pm 501.0$ & $1,077.0 \pm 492.0$ & $147.0 \pm 35.0$ & $20.0 \pm 14.0$ & $718.0 \pm 189.0$ & $234.0 \pm 76.0$ & Brito et al. (2015) \\
P. orbignyi & $2,555.0 \pm 447.0$ & $1,232.0 \pm 244.0$ & $782.0 \pm 154.0$ & $8.0 \pm 6.0$ & $403.0 \pm 113.0$ & $150.0 \pm 43.0$ & Brito et al. (2015) \\
P. scobina & $2,299.0 \pm 581.0$ & $1,736.0 \pm 583.0$ & $851.0 \pm 301.0$ & 0.0 & $594.0 \pm 169.0$ & $73.0 \pm 32.0$ & Brito et al. (2015) \\
P. wallacei & $3,700.0 \pm 2,331.0$ & $870.0 \pm 479.0$ & $776.0 \pm 343.0$ & $\mathrm{NF}$ & $1,705.0 \pm 1,078.0$ & $1,161 \pm 640.0$ & Oliveira et al. (2015) \\
P. motoro & $2,908.0 \pm 617.0$ & $816 \pm 621$ & $861 \pm 417$ & $\mathrm{NF}$ & $1.700 \pm 1262$ & $1.368 \pm 872$ & Oliveira etal.(2015) \\
P. aiereba & $2,697.0 \pm 546.0$ & $610.0 \pm 368.0$ & $899.0 \pm 1.0$ & $\mathrm{NF}$ & $1,229.0 \pm 482.0$ & $733.0 \pm 24.0$ & Oliveira et al. (2015) \\
P. orbignyi & $2,790.0 \pm 280.0$ & $1,090.0 \pm 210.0$ & $903.0 \pm 29.0$ & $\mathrm{NF}$ & $1,301.0 \pm 299.0$ & $880.0 \pm 221.0$ & Oliveira et al. (2015) \\
P. schroederi & $2,900.0 \pm 430.0$ & $1,132.0 \pm 114.0$ & $851.0 \pm 302.0$ & $\mathrm{NF}$ & $1,282.0 \pm 480.0$ & $690.0 \pm 120.0$ & Oliveira et al. (2015) \\
P. magdalenae & $6,819.5 \pm 2,966.2$ & $6,981.0 \pm 2,894.6$ & $2,550.60 \pm 1,952.0$ & $18.6 \pm 31.6$ & $4,098.1 \pm 2,684.7$ & $152.2 \pm 81.5$ & This study \\
\hline
\end{tabular}

Leu: Leukocyte count $\left(\mu \mathrm{L}^{-1}\right)$; Thr: Thrombocyte count $\left(\mu \mathrm{L}^{-1}\right)$; Het: Heterophils count $\left(\mu \mathrm{L}^{-1}\right)$; Eos: Eosinophils count $\left(\mu \mathrm{L}^{-1}\right)$; Lym: Lymphocytes count $\left(\mu \mathrm{L}^{-1}\right)$; Mon: Monocytes count $\left(\mu \mathrm{L}^{-1}\right)$; NF: Not Found. 
immune-redistribution due to biotic or abiotic factors such as seasonality, water quality conditions or confinement diets (Charbeneau, 2004; Tavares-Dias and Moraes, 2004; Sueiro et al., 2019). Since the main water parameters for fish (temperature, oxygen and pH; Baldisserotto et al., 2014) were controlled and highly similar to wildlife habitat, we consider that seasonality or water quality do not play a major role in leukocyte profile. Additionally, no dietary effects were considered since we did not use any type of supplementation for the stingray feeding and no positive relation between body condition and white blood cells that show any sign of immune improvement was found. According to this, results here obtained are more related with natural features of the species than influenced by environmental factors.

The high intraspecific variation found for white blood cells $(/ \mu \mathrm{L})$ and thrombocytes counts is consistent with previous reports in marine and freshwater batoids in both wildlife and captive environments (Brito et al., 2015; Oliveira et al., 2016b; Greene et al., 2018; Grant and Campbell, 2020). This information mean that our results might be reflecting natural features of the species since all sampled animals were in good condition, apparently good health and showing continue reproductive events. In this sense, more information is necessary in order to assess how other parameters, handling and feeding protocols can influence immune system of freshwater stingrays in artificial environments.

We found higher values of heterophils $(/ \mu \mathrm{L})$, and lymphocyte $(/ \mu \mathrm{L})$ compared with other potamotrygonids (as shown in Table 5). Since the main function of these cells is associated with innate immunological response (heterophils), or playing major role in cell-mediated immunity and antibody production (lymphocytes; Walsh and Luer, 2004; Semeniuk et al., 2009), we consider that at least one female was showing signs of immune response to ongoing infection and/or stress (high numbers of heterophils), while one male seemed to show signs of long- term infection, with high numbers of lymphocytes and low values of $\mathrm{Hb}$ and $\mathrm{Ht}$. Negative relationship found between heterophils and lymphocytes is according to the results of Semeniuk et al. (2009), and this was expected since heterophils are the first line of the immune response, but when the stressor last for long periods of time, secondary respond (lymphocytes) is activated and lymphocyte number increase (Smith et al., 2014).

Although some females showed presence of eosinophils, cells related with parasite and antigen control (Semeniuk et al., 2009; Smith et al., 2014), we did not find other evidence of parasite infection such as nuclei distribution of erythrocytes due to parasitic gametocytes (Oliveira et al., 2016a), poor body condition, low values of $\mathrm{MCH}$ and $\mathrm{MCHC}$, or significant correlations among this parameters, which allows us to indicate that parasites could not be the best explanation for our results. Additionally, although we did not conduct any hemoparasitic assessment in our animals, no ectoparasites were found in any animal (based on a recurrent environmental and physical monitoring of the animals in their artificial environment). However, we highlight the importance of periodic microbiological assessments (endo, exo and hemo parasites) in artificial environments in order to control parasite loads and prevent health issues previously reported in freshwater stingrays (Ross, 2004; Lacerda et al., 2009; Oliveira et al., 2016a).

Given the consistent levels of cholesterol and tryglicerides of $P$. magdalenae compared to other potamotrygonids (as shown in Table 6), absense of relation between K and these metabolytes, and the good condition compared to wildlife populations of this species (PérezRojas et al., unpublished data), we consider that differences in these metabolytes are more related with diet habits than health or stress issues. In this sense, cholesterol and tryglicerides were lower compared to potamotrigonids that feed with high fatty diets ( $P$. motoro, $P$. falkneri and $P$. aiereba) but similar to insectivore species as $P$. orbignyi

Table 6. Blood biochemistry comparison among freshwater stingrays, showing average and standard deviation (SD) values.

\begin{tabular}{lccccccc}
\hline Species & Ure & Tri & Chol & $\begin{array}{c}\text { Plasma } \\
\text { protein }\end{array}$ & $\begin{array}{c}\text { Serum } \\
\text { protein }\end{array}$ & Glu & Reference \\
\hline Potamotrygon sp. & $6.6 \pm 0.6$ & $\mathrm{NR}$ & $108.3 \pm 30.9$ & $\mathrm{NR}$ & $8.3 \pm 2.2$ & $21.62 \pm 3.6$ & Griffith et al. (1973) \\
$\begin{array}{l}\text { P. wallacei } \\
\text { P. falkneri }\end{array}$ & $1.2 \pm 0.6$ & $\mathrm{NR}$ & $\mathrm{NR}$ & $\mathrm{NR}$ & $\mathrm{NR}$ & $28.8 \pm 1.8$ & Brinn et al. (2012) \\
P. motoro & $29.0 \pm 3.1$ & $66.7 \pm 4.4$ & $88.7 \pm 6.4$ & $\mathrm{NR}$ & $3.0 \pm 0.1$ & $66.9 \pm 3.7$ & Brito et al. (2015) \\
P. orbignyi & $30.1 \pm 3.1$ & $52.4 \pm 7.1$ & $74.2 \pm 8.8$ & $\mathrm{NR}$ & $3.0 \pm 0.2$ & $61.8 \pm 6.7$ & Brito et al. (2015) \\
$\begin{array}{l}\text { P. cf. scobina } \\
\text { P. wallacei }\end{array}$ & $24.1 \pm 4.6$ & $37.5 \pm 2.7$ & $21.8 \pm 6.6$ & $\mathrm{NR}$ & $2.0 \pm 0.2$ & $39.0 \pm 6.5$ & Brito et al. (2015) \\
P. motoro & $10.2 \pm 3.0$ & $53.1 \pm 17.7$ & $54.1 \pm 19.3$ & $1.1 \pm 0.3$ & $\mathrm{NR}$ & $30.6 \pm 9.0$ & Oliveira et al. (2015) \\
P. aiereba & $12.6 \pm 4.8$ & $70.8 \pm 17.7$ & $65.7 \pm 15.5$ & $1.1 \pm 0.3$ & $\mathrm{NR}$ & $27.0 \pm 10.8$ & Oliveira et al. (2015) \\
P. orbignyi & $19.2 \pm 17.4$ & $99.1 \pm 53.1$ & $57.9 \pm 23.2$ & $1.7 \pm 0.3$ & $\mathrm{NR}$ & $19.8 \pm 3.6$ & Oliveira et al. (2015) \\
P. schroederi & $16.82 \pm 3.6$ & $70.0 \pm 26.25$ & $57.9 \pm 11.6$ & $1.0 \pm 0.2$ & $\mathrm{NR}$ & $39.64 \pm 1.8$ & Oliveira et al. (2015) \\
P. magdalenae & $16.22 \pm 12.61$ & $70.0 \pm 52.5$ & $69.6 \pm 11.6$ & $1.5 \pm 0.9$ & $\mathrm{NR}$ & $21.62 \pm 10.81$ & Oliveira et al. (2015) \\
\hline
\end{tabular}

Ure: Urea (mg/dL); Tri: Tryglicerides (mg/dL); Cho: Cholesterol (mg/dL); Serum protein (g/dL); Plasma protein (g/dL); Glu: Glucose (mg/dL); NR: Not Reported. 
(Shibuya et al., 2009). This is also related to the food offered to $P$. magdalenae in artificial environment since E. foetida shows low levels of fat (8.2\%, Gunya et al., 2016), and thus, support the idea that ex situ handling protocols mainly explain blood biochemical results. Findings of positive relation between plasma protein, cholesterol and triglycerides higligth the inflluence of diet in our results.

Individuals of $P$. magdalenae showed high difficulty to acclimate to new diets within the first months of ex situ acclimattion, and even, after eating earthworms it was difficult to change their diet in order to include other food items (e.g. live and frozen fish or shrimp). Thus, according to the offered diet (earthworms at $10 \%$ biomass/tank), and the fact that in wildlife this species is a high specialized insectivore predator (Márquez-Velásquez et al., 2019), we expected to find high protein levels in the results. Confirming this, blood total protein, both in plasma and serum, showed the highest levels reported in freshwater stingrays, even when compared with fish, crustacean or molluscs feeders such as $P$. motoro, $P$. aiereba, $P$. falkneri and P. wallacei (Shibuya et al., 2009; Almeida et al., 2010; Lasso et al., 2013).

Lower urea levels found in P. magdalenae compared to other species (as shown in Table 6), in addition to the negative correlation found between urea and glucose, could be a sign of ongoing stress during blood samplig. However, considering the specific blood sampling protocol that we followed (Oliveira et al., 2012) and the short amount of time each animal was under hypoxia (less 30 seconds), we consider that stressor effect might not be as acute it needs to trigger physiological responses. Considering the highly protein diet, the amoun of food offered and the feeding frequency, we expected higher rates of nitrogen excretion to be reflected in higher urea levels, but conversely, levels of blood urea were lower compared to other potamotrygonids (as shown in Table 6). This is probably because altough urea is the main excretion metabolite in marine elasmobranch, freshwater stingrays do not follow the same strategy due to the high energetic cost of convert ammonia into urea and that this process is not neccesary in the freshwater environments (Ballantyne and Robinson, 2010). In this sense, we find similar glucose levels in P. magdalenae compare to other potamotrygonids, with no significative differences between sexes, which seems to indicate that glucose levels were not influenced by stress (e.g. blood sampling) and the results are more related with specie-specific behavior or ex situ diet. In this regard, the relationship between glucose and stress in marine and freshwater stingrays is not yet clear (Brinn et al., 2012; Skomal and Mandelman, 2012; Lambert et al., 2018).

From this study, we suggest that future research in this field should consider: larger sample size in artificial environments, hematological assessment of wildlife populations of $P$. magdalenae, reproductive assessment in artificial environments using complementary techniques, complementary physiological parameters, hemoparasites and parasite loads assessment, behavioral assessment of $P$. magdalenae in artificial environments, and a global welfare assessment of the species in artificial environments including physical, physiological and behavioral aspects.
Finally, although the main objective of this research was not to provide a clinical diagnosis for P. magdalenae individuals, due to low size sample and the lack of reference values for the species, our research provide public aquariums, commercial traders, environmental authority and aquarists, with reference information that could be used for speciespecific handling, breeding and assessment protocols, considering the physical condition and physiological status of individuals, as a tool to reduce high mortality rates found in the commercial trade of $P$. magdalenae.

\section{Acknowledgements}

We thank Alba Luz Rojas and Jose Iván Pérez for funding the project; to Veterinary Clinical Diagnostic Laboratory of the Corporación Universitaria Lasallista for supporting the blood sample analysis; to Universidad Nacional de Colombia, Medellín campus for providing its facilities for the execution of this research and Animal Modeling Laboratory (LAMA) students for their commitment with caring and maintenance of the animals used in this study.

\section{References}

ADAMS, S.M., GREELEY, M.S., LAW, J.M., NOGA, E.J. and ZELIKOFF, J.T., 2003. Application of multiple sublethal stress indicators to assess the health of fish in Pamlico Sound following extensive flooding. Estuaries, vol. 26, no. 5, pp. 1365-1382. http://dx.doi. org/10.1007/BF02803638.

ALMEIDA, M.P., LINS, P.M.O., CHARVET-ALMEIDA, P. and BARTHEM, R.B., 2010. Diet of the freshwater stingray Potamotrygon motoro (Chondrichthyes: Potamotrygonidae) on Marajó Island (Pará, Brazil). Brazilian Journal of Biology = Revista Brasileira de Biologia, vol. 70, no. 1, pp. 155-162.

BACHA, A.B., KARRAY, A., BOUCHAALA, E., GARGOURI, Y. and ALI, Y.B., 2011. Purification and biochemical characterization of pancreatic phospholipase A2 from the common stingray Dasyatis pastinaca. Lipids in Health and Disease, vol. 10, no. 1, pp. 32. http://dx.doi.org/10.1186/1476-511X-10-32. PMid:21329523.

BALDISSEROTTO, B., CYRINO, J.E.P. and URBINATI, E.C., 2014. Biologia e fisiologia de peixes neotropicais de água doce. Jaboticabal: Funep, p. 336.

BALLANTYNE, J.S. and ROBINSON, J.W., 2010. Freshwater elasmobranchs: a review of their physiology and biochemistry. Journal of Comparative Physiology. B, Biochemical, Systemic, and Environmental Physiology, vol. 180, no. 4, pp. 475-493.

BELDOMENICO, P.M., TELFER, S., GEBERT, S., LUKOMSKI, L., BENNETT, M. and BEGON, M., 2008. The dynamics of health in wild field vole populations: a haematological perspective. Journal of Animal Ecology, vol. 77, no. 5, pp. 984-997. http:// dx.doi.org/10.1111/j.1365-2656.2008.01413.x. PMid:18564292.

BIRCHARD, G.F., 1997. Optimal hematocrit: theory, regulation and implications. American Zoologist, vol. 37, no. 1, pp.65-72. http:// dx.doi.org/10.1093/icb/37.1.65.

BRINN, R.P., MARCON, J.L., MCCOMB, D.M., GOMES, L.C., ABREU, J.S. and BALDISSEROTO, B., 2012. Stress responses of the endemic freshwater cururu stingray (Potamotrygon cf. histrix) during transportation in the Amazon region of the Rio Negro. Comparative Biochemistry and Physiology. Part A, Molecular E'Integrative Physiology, vol. 162, no. 2, pp. 139-145. http://dx.doi.org/10.1016/j.cbpa.2011.07.004. PMid:21777687. 
BRITO, F.M.M., CLAUDIANO, G.D.S., YUNIS, J., MUNDIM, A.V., TAVARES-DIAS, M., VIADANNA, P.H.O., MORAES, J.R. and MORAES, F.R., 2015. Hematology, biochemical profile and thyroid hormones of four species of freshwater stingrays of the genus Potamotrygon. Brazilian Journal of Veterinary Research and Animal Science, vol. 52, no. 3, pp. 249-256. http://dx.doi. org/10.11606/issn.1678-4456.v52i3p249-256.

CHARBENEAU, G.R.E.G., 2004. Physiological and behavioral changes to elasmobranchs in controlled environments. In: M. SMITH, D. WARMOLTS, D. THONEY and R. HUETER, eds. Elasmobranch husbandry manual: captive care of sharks, rays and their relatives. Columbus: Ohio Biological Survey.

DIBATTISTA, J.D., FELDHEIM, K.A., GRUBER, S.H. and HENDRY, A.P., 2007. When bigger is not better: selection against large size, high condition and fast growth in juvenile lemon sharks. Journal of Evolutionary Biology, vol. 20, no. 1, pp. 201-212. http:// dx.doi.org/10.1111/j.1420-9101.2006.01210.x. PMid:17210013.

FERREIRA, C.M., FIELD, C.L. and TUTTLE, A.D., 2010. Hematological and plasma biochemical parameters of aquarium-maintained cownose rays. Journal of Aquatic Animal Health, vol. 22, no. 2, pp. 123-128. http://dx.doi.org/10.1577/H09-048.1. PMid:20848887.

FRICKE, R., ESCHMEYER, W.N. and VAN DER LAAN R., 2019 [viewed 4 February 2020]. Eschmeyer's catalog of fishes: genera, species, references. Available from: http://researcharchive.calacademy. org/research/ichthyology/catalog/fishcatmain.asp

GALLAGHER, A.J., WAGNER, D.N., IRSCHICK, D.J. and HAMMERSCHLAG, N., 2014. Body condition predicts energy stores in apex predatory sharks. Conservation Physiology, vol. 2, no. 1, cou022. http:// dx.doi.org/10.1093/conphys/cou022. PMid:27293643.

GRANT, K. and CAMPBELL, T., 2020. Hematology and plasma biochemistry value differences between acclimated and recently captive female southern stingrays, Dasyatis americana. The Journal of Zoo and Aquarium Research, vol. 8, no. 1, pp. 59-66.

GRANT, K.R., 2015. Fish hematology and associated disorders. The Veterinary Clinics of North America. Exotic Animal Practice, vol. 18, no. 1, pp. 83-103. http://dx.doi.org/10.1016/j.cvex.2014.09.007. PMid:25421028.

GREENE, W., BROOKSHIRE, G. and DELAUNE, A.J., 2018. Hematologic and biochemical summary statistics in aquarium-housed spotted eagle rays (Aetobatus narinari). Journal of Zoo and Wildlife Medicine, vol. 49, no. 4, pp. 912-924. http://dx.doi. org/10.1638/2017-0203.1. PMid:30592936.

GRIFFITH, R.W., PANG, P.K., SRIVASTAVA, A.K. and PICKFORD, G.E., 1973. Serum composition of freshwater stringrays (Potamotrygonidae) adapted to fresh and dilute sea water. The Biological Bulletin, vol. 144, no. 2, pp. 304-320. http://dx.doi. org/10.2307/1540010.

GUNYA, B., MASIKA, P.J., HUGO, A. and MUCHENJE, V., 2016. Nutrient composition and fatty acid profiles of oven-dried and freezedried earthworm Eisenia foetida. Journal of Food and Nutrition Research, vol. 4, no. 6, pp. 343-348.

HAMMER, Ø., HARPER, D.A.T. and RYAN, P.D., 2001. PAST: paleontological statistics software package for education and data analysis. Palaeontologia Electronica, vol. 4, no. 1, pp. 1-9.

HAMMERSCHLAG, N., SKUBEL, R.A., SULIKOWSKI, J., IRSCHICK, D.J. and GALLAGHER, A.J., 2018. A comparison of reproductive and energetic states in a marine apex predator (the tiger shark, Galeocerdo cuvier). Physiological and Biochemical Zoology, vol. 91, no. 4, pp. 933-942. http://dx.doi.org/10.1086/698496. PMid:29782225.

IRSCHICK, D.J. and HAMMERSCHLAG, N., 2014. A new metric for measuring condition in large predatory sharks. Journal of Fish Biology, vol. 85, no. 3, pp. 917-926. http://dx.doi.org/10.1111/ jfb.12484. PMid:25130454.
JAIN, S., GAUTAM, V. and NASEEM, S., 2011. Acute-phase proteins: as diagnostic tool. Journal of Pharmacy \& Bioallied Sciences, vol. 3, no. 1, pp. 118-127. http://dx.doi.org/10.4103/0975-7406.76489. PMid:21430962.

JEROME, J.M., GALLAGHER, A.J., COOKE, S.J. and HAMMERSCHLAG, N., 2018. Integrating reflexes with physiological measures to evaluate coastal shark stress response to capture. ICES Journal of Marine Science, vol. 75, no. 2, pp. 796-804. http://dx.doi. org/10.1093/icesjms/fsx191.

LACERDA, A.C.F., TAKEMOTO, R.M. and PAVANELLI, G.C., 2009. Ecology of endoparasites of the fluvial stingray Potamotrygon falkneri (Chondrichthyes: Potamotrygonidae) from the upper Paraná River floodplain, Brazil. Brazilian Journal of Biology = Revista Brasileira de Biologia, vol. 69, no. 2, pp. 297-303. http://dx.doi.org/10.1590/S1519-69842009000200009. PMid:19675930.

LAMBERT, F.N., TREBERG, J.R., ANDERSON, W.G., BRANDT, C. and EVANS, A.N., 2018. The physiological stress response of the Atlantic stingray (Hypanus sabinus) to aerial exposure. Comparative Biochemistry and Physiology. Part A, Molecular \& Integrative Physiology, vol. 219-220, pp. 38-43. http://dx.doi.org/10.1016/j.cbpa.2018.02.009. PMid:29482030.

LASSO, C.A., ROSA, R.S., SÁNCHEZ-DUARTE, P., MORALESBETANCOURT, M.A. and AGUDELO-CÓRDOBA, E., eds., 2013. IX. Rayas de água dulce (Potamotrygonidae) de Suramérica. Parte I. Colombia, Venezuela, Ecuador, Perú, Brasil, Guyana, Surinam y Guayana Francesa: diversidad, bioecologia, uso y conservación. Bogotá, D.C.: Instituto de Investigación de los Recursos Biológicos Alexander von Humboldt, 368 p. Serie Editorial Recursos Hidrobiológios y Pesqueros Continentales de Colombia.

MÁRQUEZ-VELÁSQUEZ, V., ROSA, R.S., GALINDO, E. and NAVIA, A.F., 2019. Feeding habits and ecological role of the freshwater stingray Potamotrygon magdalenae (Duméril 1865) (Myliobatiformes: Potamotrygonidae), combining gutcontent and stable isotope analysis. Environmental Biology of Fishes, vol. 102, no. 8, pp. 1119-1136. http://dx.doi.org/10.1007/ s10641-019-00897-0.

MEJÍA-FALLA, P.A., MUÑOZ-OSORIO, L.A., GALINDO, E., LÓPEZ, L., PÉREZ-ROJAS, J.G. and NAVIA, A.F., 2014. Evaluación de la dinámica pesquera y la distribución de P. magdalenae en la cuenca del Magdalena y aportes a su historia de vida. Cali: Fundación Colombiana para la Investigación y Conservación de Tiburones y Rayas, 58 p. Technical report AUNAP-CI.

MEJÍA-FALLA, P.A., PÉREZ-ROJAS, J.G., GÓMEZ-MARTÍNEZ, D., MUÑOZ-OSORIO, L.A., GALINDO, E., LÓPEZ-GARCÍA, J., PEDREROS, T.M., FERNÁNDEZ, G. and NAVIA, A.F., 2016. Avances en el conocimiento de Potamotrygon magdalenae (Dumeril, 1865), raya dulceacuícola endémica de Colombia. In: A. SHIBUYA, J.A.S. ZUANON and M. CARVALHO, eds. Rayas de água dulce (Potamotrygonidae) de Suramérica. Parte II: Colombia, Brasil, Perú, Bolivia, Paraguay, Uruguay y Argentina. Bogotá, D.C.: Instituto de Investigación de los Recursos Biológicos Alexander von Humboldt, 368 p. Serie Editorial Recursos Hidrobiológios y Pesqueros Continentales de Colombia.

MEJÍA-FALLA, P.A., RAMÍREZ-LUNA, V., USMA, J.S., MUÑOZ-OSORIO, L.A., MALDONADO-OCAMPO, J.A., SANABRIA, A.I. and ALONSO, J.C., 2009. Estado del conocimiento de las rayas dulceacuícolas de Colombia. In: V. PUENTES, A.F. NAVIA, P.A. MEJÍA-FALLA, J.P. CALDAS, M.C. DIAZGRANADOS and L.A. ZAPATA-PADILLA, eds. Avance en el conocimiento de tiburones, rayas y quimeras de Colombia. Colombia: Fundación SQUALUS, Ministerio de Ambiente Vivienda y Desarrollo Territorial, Instituto Colombiano Agropecuario, COLCIENCIAS, Conservación Internacional, WWF Colombia, Cap. V, pp. 195-245. 
OCHS, C.L. and DAWSON, R.D., 2008. Patterns of variation in leucocyte counts of female tree swallows, Tachycineta bicolor: repeatability over time and relationships with condition and costs of reproduction. Comparative Biochemistry and Physiology. Part A, Molecular E Integrative Physiology, vol. 150, no. 3, pp. 326-331. http://dx.doi.org/10.1016/j.cbpa.2008.04.003. PMid:18485771.

OLIVEIRA, A.T., ARAÚJO, M.L.G., LEMOS, J.R.G., SANTOS, M.Q.C. PANTOJA-LIMA, J., ARIDE, P.H.R., TAVARES-DIAS, M. and MARCON, J.L., 2016a. Ecophysiological interactions and water-related physicochemical parameters among freshwater stingrays. Brazil. Brazilian Journal of Biology = Revista Brasileira de Biologia, vol. 77, no. 3, pp. 616-621. http://dx.doi.org/10.1590/1519-6984.01816. PMid:27783760.

OLIVEIRA, A.T., LEMOS, J.R., SANTOS, M.Q., ARAÚJO, M.L.G., TAVARES-DIAS, M. and MARCON, J.L., 2012. Procedimentos de manuseio e coleta sanguínea em arraias de água doce. Macapá: Embrapa Amapá, 22 p.

OLIVEIRA, A.T., SANTOS, M.Q.D.C., ARAÚJO, M.L.G., LEMOS, J.R.G., SALES, R.S.A., ARIDE, P.H.R., PANTOJA-LIMA, J., TAVARES-DIAS, M. and MARCON,J.L., 2016b. Hematological parameters of three freshwater stingray species (Chondrichthyes: Potamotrygonidae) in the middle Rio Negro, Amazonas state. Biochemical Systematics and Ecology, vol. 69, pp. 33-40. http://dx.doi.org/10.1016/j.bse.2016.07.002.

OLIVEIRA, A.T.D., LIMA, J.P., ARIDE, P.H.R., TAVARES-DIAS, M. and MARCON, J.L., 2015. Fisiologia de arraias de água doce: subsídios para aplicabilidade na aquicultura. In: M. TAVARES-DIAS and W.S. MARIANO, eds. Aquicultura no Brasil: novas perspectivas. São Carlos: Pedro \& João Editores, 429 p.

PÁDUA, S.B., VENTURA, A.S., SATAKE, F. and ISHIKAWA, M.M., 2010. Características morfológicas, morfométricas e citoquímicas das células sanguíneas da arraia ocelata Potamotrygon motoro (Elasmobranchii, Potamotrygonidae): estudo de caso. Ensaios e Ciência, vol. 14, no. 1, pp. 147-158.

PÉREZ-ROJAS, J.G., 2020. Herramientas para la valoración del bienestar animal de la raya de río Potamotrygon magdalenae, en cautiverio. Medellin: Universidad Nacional de Colombia, 84 p. M.Sc. Thesis in Ciencias Agrarias.

RICKER, W., 1975. Computation and interpretation of biological statistics of fish populations. Canada: Board of Canada, pp. 191-382. Bulletin Fisheries Research.

ROSA, R., 1985. An asystematic revision of the South American freshwater stingrays (Chondricthyes: Potamotrygonidae). Williamsburg, Virginia: College of William and Mary, 524 p. Ph.D. Thesis in Philosophy.
ROSS, R. (2004). Husbandry of freshwater stingrays of the family Potamotrygonidae. In: M. SMITH, D. WARMOLTS, D. THONEY and R. HUETER, eds. Elasmobranch husbandry manual: captive care of sharks, rays and their relatives. Columbus: Ohio Biological Survey.

SEMENIUK, C.A., BOURGEON, S., SMITH, S.L. and ROTHLEY, K.D., 2009. Hematological differences between stingrays at tourist and non-visited sites suggest physiological costs of wildlife tourism. Biological Conservation, vol. 142, no. 8, pp. 1818-1829. http://dx.doi.org/10.1016/j.biocon.2009.03.022.

SHIBUYA, A., ARAÚJO, M.L.G. and ZUANON, J.A., 2009. Analysis of stomach contents of freshwater stingrays (Elasmobranchii, Potamotrygonidae) from the middle Negro River, Amazonas, Brazil. Pan-American Journal of Aquatic Sciences, vol. 4, no. 4, pp. 466-475.

SKOMAL, G.B. and MANDELMAN, J.W., 2012. The physiological response to anthropogenic stressors in marine elasmobranch fishes: a review with a focus on the secondary response. Comparative Biochemistry and Physiology. Part A, Molecular E Integrative Physiology, vol. 162, no. 2, pp. 146-155. http://dx.doi.org/10.1016/j.cbpa.2011.10.002. PMid:22008842.

SMITH, S.L., SIM, R.B. and FLAJNIK, M.F., 2014. Immunobiology of the shark. Boca Raton: CRC Press, 322 p. http://dx.doi. org/10.1201/b17773.

SUEIRO, M.C., AWRUCH, C.A., IRIGOYEN, A.J., ARGEMI, F. and PALACIOS, M.G., 2019. Seasonality of immunological and healthstate parameters of wild broadnose sevengill shark, Notorynchus cepedianus. Physiological and Biochemical Zoology, vol. 92, no. 1, pp. 24-36. http://dx.doi.org/10.1086/700573. PMid:30452332.

TAVARES-DIAS, M. and MORAES, F.R., 2004. Hematologia de peixes teleósteos. Ribeirão Preto: Villimpress, 144 p.

TAVARES-DIAS, M. and MORAES, F.R., 2007. Haematological and biochemical reference intervals for farmed channel catfish. Journal of Fish Biology, vol. 71, no. 2, pp. 383-388. http://dx.doi. org/10.1111/j.1095-8649.2007.01494.x.

WALSH, C.J. and LUER, C.A., 2004. Elasmobranch hematology: identification of cell types and practical applications. In: M. SMITH, D. WARMOLTS, D. THONEY and R. HUETER, eds. Elasmobranch husbandry manual: captive care of sharks, rays and their relatives. Columbus: Ohio Biological Survey, pp. 307-323.

WINTROBE, M.M., 1933. Macroscopic examination of the blood. The American Journal of the Medical Sciences, vol. 185, pp. 58-71. 